\title{
Harvest season, productivity and physicochemical quality of peach fruits grown in Dois Vizinhos, Paraná State, Brazil
}

\section{Época de colheita, produtividade e qualidade físico-química de frutos de pessegueiros cultivados em Dois Vizinhos, PR}

\author{
Gilmar Antônio Nava ${ }^{1 *}$; Eder Oneide Kurschner²; Dalva Paulus ${ }^{1}$
}

\section{Highlights:}

Fruits of the Rubimel cultivar matured earliest and fruits of the Eldorado cultivar, latest.

The average yield of the evaluated peach cultivars was $5.3 \mathrm{tha}^{-1}$, ranging from 1.2 to $15.5 \mathrm{t} \mathrm{ha}^{-1}$.

The cultivars Bonão, Charme and Eldorado were the most productive.

The availability of winter cold in 2016 was $73 \%$ greater than in 2017.

The 2016 crop season provided higher productivity, with fruits of greater biomass and firmness of pulp.

\begin{abstract}
The objective of this study was to determine the harvest time, main components of yield and the physicochemical quality attributes of peach cultivars produced in a subtropical climate. The study was carried out in the Fruit Growing sector of the Federal Technological University of Paraná, Campus Dois Vizinhos, Paraná State, Brazil. The main components of yield and estimated productivity, background color of the epidermis, pulp firmness, soluble solids (SS), titratable acidity (TA) and the SS/TA ratio of 17 peach cultivars were determined for two crop cycles: 2016 and 2017. The experimental design was a randomized block with four replicates of one tree per experimental unit, in a 17 x 2 bifactorial scheme (cultivars x years). Fruits of the cultivars: Aurora-1, Bonão, Douradão, Leonense, Ouromel, Rubimel and Zilli matured early, whereas those of Eldorado and BR-1 were last to mature. The cultivars Bonão, Charme and Eldorado were the most productive. Eldorado produced the highest caliber of fruits and Bonão produced the highest number of fruits per tree. The cultivars BR-1 and Eldorado produced the sweetest fruits and Leonense, the most acidic. The 2016 crop season provided greater productivity, with fruits of greater caliber and firmness of pulp.
\end{abstract}

Key words: Quality attributes of fruits. Prunus persica L. Batsch. Season of maturity. Yield.

\section{Resumo}

O objetivo do trabalho foi determinar a época de colheita, os principais componentes de rendimento e atributos de qualidade físico-química de cultivares de pessegueiro produzidos em Dois Vizinhos, PR. O trabalho foi realizado no setor de Fruticultura da Universidade Tecnológica Federal do Paraná, Campus Dois Vizinhos. Obteve-se em duas safras agrícolas, 2016 e 2017, as datas de início de colheita, os principais componentes de rendimento e a produtividade estimada, cor de fundo da epiderme, firmeza de polpa, teores de sólidos solúveis (SS) e acidez titulável (AT), bem como a relação SS/AT (ratio) de 17 cultivares de pessegueiros. O delineamento experimental foi de blocos ao acaso com quatro

\footnotetext{
1 Profs. Drs., Universidade Tecnológica Federal do Paraná, UTFPR, Dois Vizinhos, PR, Brasil. E-mail: gilmarnava@utfpr.edu.br; dalvapaulus@utfpr.edu.br

2 Discente do Curso Agronomia, UTFPR, Dois Vizinhos, PR, Brasil. E-mail: ederkurschner@gmail.com

* Author for correspondence
} 
repetições de uma planta por unidade experimental, num esquema bifatorial 17 x 2 (cultivares $\mathrm{x}$ anos de cultivo). Os frutos das cultivares Aurora-1, Bonão, Douradão, Leonense, Ouromel, Rubimel e Zilli amadureceram mais cedo, enquanto os de Eldorado e BR-1 foram os últimos a amadurecer. As cultivares Bonão, Charme e Eldorado foram as mais produtivas. Eldorado produziu o maior calibre de frutos e Bonão produziu o maior número de frutos por planta. As cultivares BR-1 e Eldorado produziram os frutos mais doces e Leonense, os mais ácidos. A safra de 2016 proporcionou maior produtividade, com frutos de maior calibre e firmeza da polpa.

Palavras-chave: Atributos de qualidade de frutos. Prunus persica L. Batsch. Época de maturação. Produtividade.

\section{Introduction}

The peach (Prunus persica L. Batsch) is a fruit species of temperate climates that needs cold during the winter rest period to overcome dormancy. However, nowadays, it is also being cultivated in subtropical and tropical regions, where there is less occurrence or even total absence of cold during this phenological phase (Souza et al., 2017). This region presents great variability in the requirement for winter cold between cultivars, as well as in the average fruit biomass and in productivity (Della Bruna, Moreto, \& Dalbó, 2012).

In 2018, Brazil produced 219,598 t of peaches, cultivated over an area of 17,605 ha. By state, the biggest producers of the 2018 peach yield were Rio Grande do Sul (146,431 t), São Paulo (34,640 t), Santa Catarina $(18,587$ t), Paraná (11,781 t), and Minas Gerais (7,845 t) (Instituto Brasileiro de Geografia e Estatística [IBGE], 2020).

The lack of adaptation of peach cultivars to mild winters can cause insufficient and sporadic flowering, which limits fruit production (Scariotto, Citadin, Raseira, Sachet, \& Penso, 2013). However, according to Citadin et al. (2014), temperatures between $7.2{ }^{\circ} \mathrm{C}$ and $12{ }^{\circ} \mathrm{C}$ can be effective in overcoming the endodormancy of the buds of cultivars with low cold requirements.

Knowledge of the adaptability and stability of fruit production in different locations or between years is crucial for increasing the potential of agricultural production (Matias, Bruckner, Silva,
Carneiro, \& Oliveira, 2017). In order to make the cultivation of peaches technically and economically viable in regions with a low occurrence of winter cold, the choice of well adapted cultivars is one of the first actions needed to improve orchard yield (Souza, Ramos, Lima, Florentino, \& Escobedo, 2011).

Knowing the expected harvest date of a cultivar can help peach producers to plan crop management practices efficiently and, consequently, increase fruit productivity and quality (Day, Lopes, \& Dejong, 2008; Leonel, Pierozzi, \& Tecchio, 2011). Thus, this study investigated the time of harvest, main components of fruit yield, and physicochemical quality of peaches produced in a region with low cold accumulation.

\section{Materials and Methods}

The study was carried out in the Fruit sector of the Federal Technological University of Paraná,

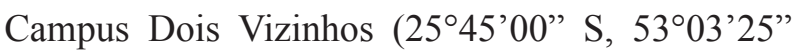
$\mathrm{W}$, at $546 \mathrm{~m}$ elevation (Instituto Nacional de Meteorologia [INMET], 2018). The local climate is humid and subtropical (Köppen classification: $\mathrm{Cfa}$ ) with an average annual temperature of $22{ }^{\circ} \mathrm{C}$ in the hottest months, below $18{ }^{\circ} \mathrm{C}$ in the coldest months, and an average rainfall of 2,025 $\mathrm{mm}$ year ${ }^{-1}$ (Alvares, Stape, Sentelhas, Gonçalves, \& Sparovek, 2013).

The peach tree cultivars evaluated during the 2016 and 2017 crop cycles were: Aurora-1, Bonão, BR-1, Charme, Chimarrita, Coral, Douradão, 
Eldorado, Fascínio, Kampai, Leonense, Maciel, Marli, Ouromel, Regalo, Rubimel, and Zilli, all on the Capdeboscq rootstock. Trees were treeed at a spacing of $4.0 \times 5.0 \mathrm{~m}$ in the orchard. The experimental design was completely randomized, with four replications of one tree per experimental unit in a 17 x 2 bifactorial scheme (cultivars x years). The Fascínio, Kampai, Regalo, and Zilli cultivars were treeed in 2014, and the others in 2010. The tree conduction system adopted was the vase. All the trees were managed according to the precepts of integrated peach production (Fachinello, Coutinho, Marodin, Botton, \& May De Mio, 2003).

At the bud swelling stage of each cultivar, a mixture of $0.5 \%$ hydrogenated cyanamide and 1.0 $\%$ mineral oil was applied to the buds to artificially stimulate budding and floral opening. When the fruits of each cultivar reached 15 to $20 \mathrm{~mm}$ in diameter, manual fruit thinning was performed to a distance of 8 to $10 \mathrm{~cm}$ between fruits. After 15 days of fruit thinning for each cultivar, the remaining fruits were counted per tree using a manual register.

Evaluated during the harvest windows: date of the start of the fruit harvest, number of fruits per tree, fresh fruit biomass $(\mathrm{g})$, production ( $\mathrm{kg}$ per tree) $=[$ fruits per tree $\mathrm{x}$ fresh biomass of fruits $(\mathrm{g})] / 1000$, and productivity $\left(\mathrm{tha}^{-1}\right)=\left[\mathrm{kg}\right.$ per tree $\mathrm{x}$ trees $\mathrm{ha}^{-1}(\mathrm{n}$ $=500)] / 1000$. Fresh fruit biomass was determined with all the fruits harvested per tree using a semianalytical balance Shimadzu BL3200H.

From the largest harvest of each cultivar (full harvest), 10 fruits per experimental unit (tree) were randomly sampled for physicochemical analysis. The parameters $L^{*}$ (lightness) and the coordinates $a^{*}$ and $b^{*}$ of the background color of the epidermis of these fruits were evaluated with a digital colorimeter Konica-Minolta CR400. Pulp firmness was determined using a manual penetrometer
Instruterm PTR-100 with an $8 \mathrm{~mm}$ diameter tip. The soluble solids (SS) content was measeued by digital refractometer Hanna HI96801 and the values were corrected for a temperature of $20^{\circ} \mathrm{C}$. The levels of titratable acidity (TA) were obtained by titration using a digital $\mathrm{pH}$ meter BEL PHS3BW, from aliquots of $10 \mathrm{ml}$ of juice obtained from a juicertype centrifuge Mondial CF-01 in $90 \mathrm{ml}$ of distilled water, with $0.1 \mathrm{~N}$ of $\mathrm{NaOH}$ until $\mathrm{pH} 8.1$. The results of these analyses were used to calculate the SS/TA ratio for each cultivar.

The Lilliefors Normality test and the required transformations were applied to the average data: Root $(Y i j+1 / 2)$ for number of fruits per tree, parameter $L^{*}$ for background color, and for SS/TA ratio e; $\log _{10}(Y i j+1)$ for productivity, parameters $a^{*}$ and $b^{*}$ for background color, and SS. Using the statistical program Genes (Cruz, 2006), the data were subjected to variance analysis and, when significant, the averages were grouped by the Scott $\&$ Knott test $(p \leq 0.05)$.

\section{Results}

\section{Fruit harvest dates}

In 2016, the cultivars that showed earlier fruit maturation were Aurora-1, Bonão, Douradão, and Ouromel (10 October), followed by Rubimel and Zilli (14 October), whereas later fruit maturation was displayed by BR-1(25 November) and Eldorado (2 December). In 2017, the earliest ripening cultivars were Rubimel and Leonense (12 October), followed by Coral and Zilli (18 and 19 October, respectively) and then by Marli and Ouromel (22 October), and Bonão (23 October). The cultivars Eldorado and BR-1 again showed the latest fruit maturation, from mid-November (Table 1). 
Table 1

Harvest start dates (day/month) for the different peach cultivars during the 2016 and 2017 crop cycles. Dois Vizinhos, Paraná State, Brazil

\begin{tabular}{lccc}
\hline Cultivars & $\mathbf{2 0 1 6}$ & $\mathbf{2 0 1 7}$ & Dates \\
\hline Aurora-1 & $10 / 10$ & $26 / 10$ & $18 / 10$ \\
Bonão & $10 / 10$ & $23 / 10$ & $16 / 10$ \\
BR-1 & $25 / 11$ & $17 / 11$ & $21 / 11$ \\
Charme & $03 / 11$ & $26 / 10$ & $30 / 10$ \\
Chimarrita & $07 / 11$ & $26 / 10$ & $01 / 11$ \\
Coral & $09 / 11$ & $18 / 10$ & $29 / 10$ \\
Douradão & $10 / 10$ & $26 / 10$ & $18 / 10$ \\
Eldorado & $02 / 12$ & $20 / 11$ & $26 / 11$ \\
Fascínio & $11 / 11$ & $26 / 10$ & $03 / 11$ \\
Kampai & $03 / 11$ & $26 / 10$ & $30 / 10$ \\
Leonense & $(-)$ & $18 / 10$ & $18 / 10$ \\
Maciel & $16 / 11$ & $14 / 11$ & $15 / 11$ \\
Marli & $07 / 11$ & $22 / 10$ & $30 / 10$ \\
Ouromel & $10 / 10$ & $22 / 10$ & $16 / 10$ \\
Regalo & $11 / 11$ & $14 / 11$ & $12 / 11$ \\
Rubimel & $14 / 10$ & $12 / 10$ & $13 / 10$ \\
Zilli & $14 / 10$ & $19 / 10$ & $16 / 10$ \\
\hline
\end{tabular}

(-) No information.

\section{Fruit yield components}

After standard thinning, the average number of fruits per tree (145) was similar between the 2016 and 2017 crops. Except for Aurora-1, Kampai, Ouromel, and Rubimel, which had the highest number of fruits per tree in 2017, all the other cultivars either had their highest fruit number in 2016, or statistically equal fruit numbers between the two crop cycles. Comparing the cultivars within each crop cycle, Bonão produced the highest number of fruits in 2016, and in 2017, Aurora-1, Bonão, Kampai, and Ouromel were the top producers (Table 2).

All cultivars produced a higher fresh fruit biomass during the 2016 season, except BR-1, Fascínio, and Leonense, which were statistically equal between the two crops (Table 2). In 2016, the cultivars Eldorado and Marli produced the largest fruits, both averaging $128.6 \mathrm{~g}$, followed by the fruit sizes of Charme, Chimarrita, Coral, Douradão, Leonense, Maciel, Rubimel, and Zilli. The cultivar BR-1 (47.3 g) produced fruits with the lowest fresh biomass. In 2017, the cultivars Chimarrita, Eldorado, Fascínio, Leonense, Rubimel, and Zilli produced the largest fruits, whereas the fruits of the Aurora-1 and Ouromel cultivars were the smallest (Table 2).

The average productivity of the peach cultivars was $5.3 \mathrm{t} \mathrm{ha}^{-1}$ (Table 2) which was substantially lower than the Brazilian average of $17 \mathrm{t} \mathrm{ha}^{-1}$ in the 2016-2017 crop season (IBGE, 2020).

The productivity of most cultivars was higher in 2016 than 2017, probably the result of greater fruit development. The most productive cultivars (t ha ${ }^{-1}$ ) were Bonão (20.2), Charme (16.7), and Eldorado (14.5) (Table 2), with Bonão above, and Charme close to the national average of peach tree 
productivity (IBGE, 2020). In 2017, cultivars with fruit productivity in 2017 could have been due to less statistically significant low productivity $\left(\mathrm{t} \mathrm{ha}^{-1}\right)$ rainfall and higher average September temperatures were Zilli (2.4), Marli (2.1), Coral (1.4), BR-1 (1.1), than in the same period in 2016 (Figure 1).

Leonense (0.9), and Regalo (0.8) (Table 2). Lower

Table 2

Fruit yield components of peach cultivars during the 2016 and 2017 crop cycles. Dois Vizinhos, Paraná States, Brazil

\begin{tabular}{|c|c|c|c|c|c|c|c|c|c|}
\hline \multirow{2}{*}{$\begin{array}{l}\text { Cultivar/ } \\
\text { Year }\end{array}$} & \multicolumn{3}{|c|}{ Number of fruits/ tree } & \multicolumn{3}{|c|}{ Fresh fruit biomass (g) } & \multicolumn{3}{|c|}{ Productivity $\left(\mathrm{t}\right.$ ha $\left.^{-1}\right)$} \\
\hline & 2016 & 2017 & Average & 2016 & 2017 & Average & 2016 & 2017 & Average \\
\hline Aurora-1 & $232 \mathrm{bB} *$ & $387 \mathrm{aA}$ & 309 & $71.1 \mathrm{dA}$ & $36.9 \mathrm{cB}$ & 54.0 & $8.3 \mathrm{bA}$ & $7.1 \mathrm{aA}$ & 7.7 \\
\hline Bonão & $595 \mathrm{aA}$ & $262 \mathrm{aB}$ & 429 & $66.3 \mathrm{dA}$ & $51.8 \mathrm{bB}$ & 59.0 & $20.2 \mathrm{aA}$ & $6.8 \mathrm{aB}$ & 15.5 \\
\hline BR-1 & $170 \mathrm{cA}$ & $43 \mathrm{cB}$ & 89 & $47.3 \mathrm{eA}$ & $51.4 \mathrm{bA}$ & 49.3 & $4.2 \mathrm{cA}$ & $1.1 \mathrm{bB}$ & 2.6 \\
\hline Charme & $366 \mathrm{bA}$ & $188 \mathrm{bB}$ & 277 & $93.8 \mathrm{bA}$ & $64.2 \mathrm{bB}$ & 79.0 & $16.7 \mathrm{aA}$ & $6.0 \mathrm{aB}$ & 11.3 \\
\hline Chimarrita & $60 \mathrm{dA}$ & $93 \mathrm{cA}$ & 76 & $104.6 \mathrm{bA}$ & $76.5 \mathrm{aB}$ & 90.5 & $3.1 \mathrm{dA}$ & $3.6 \mathrm{aA}$ & 3.3 \\
\hline Coral & $56 \mathrm{dA}$ & $54 \mathrm{cA}$ & 55 & $108.4 \mathrm{bA}$ & $53.8 \mathrm{bB}$ & 81.1 & $3.0 \mathrm{dA}$ & $1.4 \mathrm{bA}$ & 2.2 \\
\hline Douradão & $103 \mathrm{cA}$ & $149 \mathrm{bA}$ & 126 & $101.5 \mathrm{bA}$ & $59.6 \mathrm{bB}$ & 80.6 & $5.3 \mathrm{cA}$ & $4.4 \mathrm{aA}$ & 4.8 \\
\hline Eldorado & $234 \mathrm{bA}$ & $138 \mathrm{bA}$ & 186 & $128.6 \mathrm{aA}$ & $74.9 \mathrm{aB}$ & 101.7 & $14.5 \mathrm{aA}$ & $5.1 \mathrm{aB}$ & 9.8 \\
\hline Fascínio & $83 \mathrm{dA}$ & $146 \mathrm{bA}$ & 114 & $86.9 \mathrm{cA}$ & $76.7 \mathrm{aA}$ & 81.8 & $3.7 \mathrm{cA}$ & $5.3 \mathrm{aA}$ & 4.5 \\
\hline Kampai & $44 \mathrm{~dB}$ & $250 \mathrm{aA}$ & 147 & $81.0 \mathrm{cA}$ & $51.7 \mathrm{bB}$ & 66.4 & $1.8 \mathrm{~dB}$ & $6.4 \mathrm{aA}$ & 4.1 \\
\hline Leonense & $34 \mathrm{dA}$ & $22 \mathrm{cA}$ & 28 & $92.5 \mathrm{bA}$ & $80.3 \mathrm{aA}$ & 86.4 & $1.6 \mathrm{dA}$ & $0.9 \mathrm{bA}$ & 1.2 \\
\hline Maciel & $118 \mathrm{cA}$ & $112 \mathrm{cA}$ & 115 & $99.8 \mathrm{bA}$ & $59.1 \mathrm{bB}$ & 79.4 & $5.5 \mathrm{cA}$ & $3.3 \mathrm{aA}$ & 4.4 \\
\hline Marli & $79 \mathrm{dA}$ & $75 \mathrm{cA}$ & 77 & $128.6 \mathrm{aA}$ & $53.6 \mathrm{bB}$ & 91.1 & $5.2 \mathrm{cA}$ & $2.1 \mathrm{bB}$ & 3.6 \\
\hline Ouromel & $130 \mathrm{cB}$ & $272 \mathrm{aA}$ & 201 & $88.5 \mathrm{cA}$ & $43.1 \mathrm{cB}$ & 65.8 & $5.7 \mathrm{cA}$ & $5.9 \mathrm{aA}$ & 5.8 \\
\hline Regalo & $62 \mathrm{dA}$ & $25 \mathrm{cA}$ & 43 & $76.3 \mathrm{dA}$ & $61.3 \mathrm{bB}$ & 68.8 & $2.2 \mathrm{dA}$ & $0.8 \mathrm{bA}$ & 1.5 \\
\hline Rubimel & $42 \mathrm{~dB}$ & $150 \mathrm{bA}$ & 96 & $107.5 \mathrm{bA}$ & $71.5 \mathrm{aB}$ & 89.5 & $2.2 \mathrm{~dB}$ & $5.4 \mathrm{aA}$ & 3.8 \\
\hline Zilli & $144 \mathrm{cA}$ & $61 \mathrm{cB}$ & 103 & $98.8 \mathrm{bA}$ & $79.7 \mathrm{aB}$ & 89.3 & $7.1 \mathrm{bA}$ & $2.4 \mathrm{bB}$ & 4.7 \\
\hline Average & 150 & 141 & 145 & 93.0 & 61.5 & 77.3 & 6.5 & 4,0 & 5.3 \\
\hline CV (\%) & 25.0 & & & 11.8 & & & & & \\
\hline
\end{tabular}

*Means followed by the same lowercase letter in columns and uppercase in rows, do not differ among themselves as determined by the Scott \& Knott test ( $\mathrm{p} \leq 0.05) ; \mathrm{CV}=$ Coefficient of variation. 

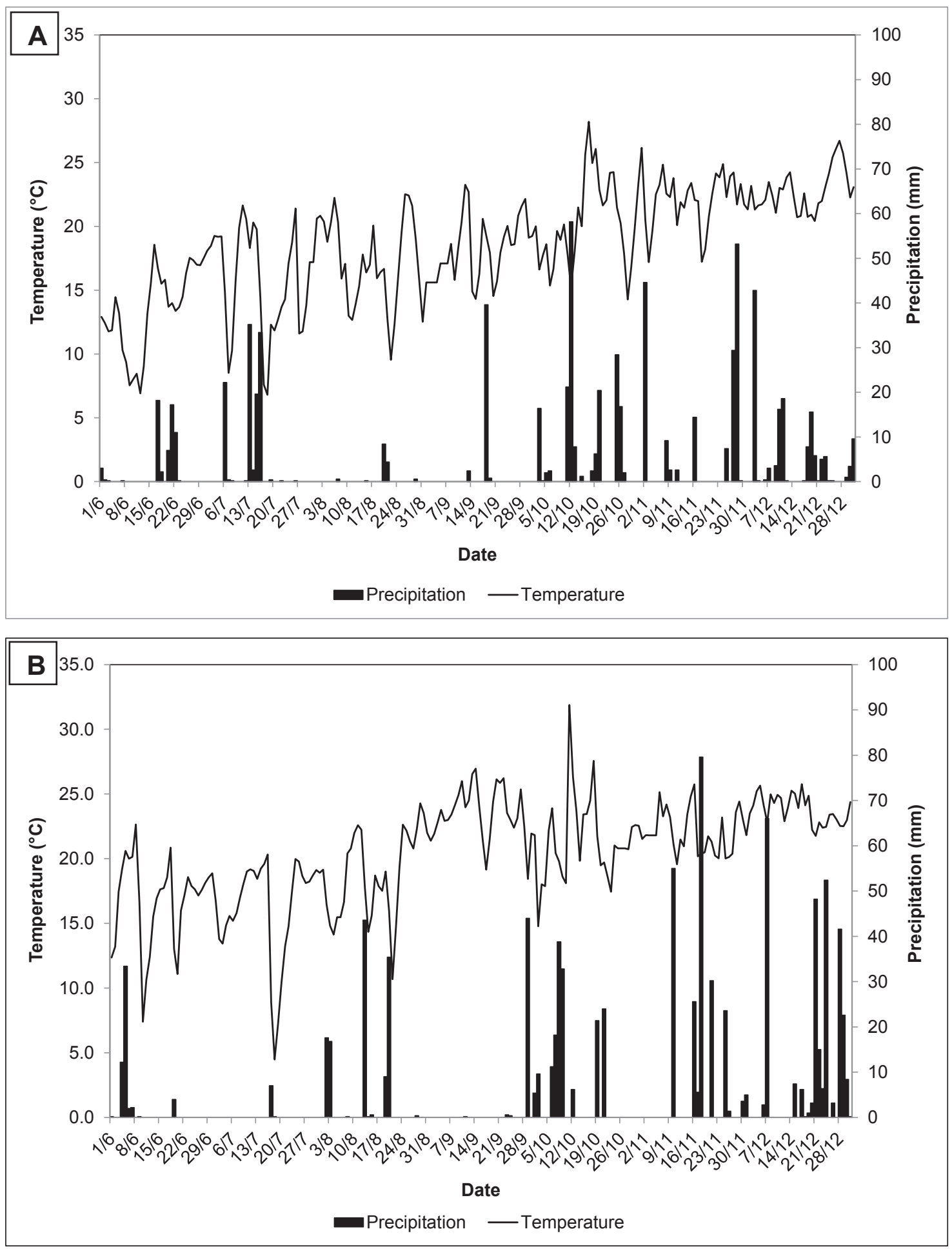

Figure 1. Average daily air temperature and rainfall recorded at the INMET station, from 1 June to 31 December in 2016 (A) and 2017 (B). Dois Vizinhos, Paraná State, Brazil.

\section{Physicochemical fruit quality}

Regarding the chemical fruit quality of the fruits, interaction between cultivars and the 2016 and 2017 crop cycles was observed for SS and TA contents, and the SS/TA ratio (Table 3 ). 
Table 3

Chemical fruit quality of peach cultivars produced during the 2016 and 2017 crop cycles. Dois Vizinhos, Paraná States, Brazil

\begin{tabular}{lccccccccc}
\hline Cultivar/ & \multicolumn{3}{c}{ SS ( ${ }^{\circ}$ Brix) } & \multicolumn{3}{c}{ TA (\%) } & \multicolumn{3}{c}{ SS/TA ratio } \\
\cline { 2 - 9 } Year & $\mathbf{2 0 1 6}$ & $\mathbf{2 0 1 7}$ & Average & $\mathbf{2 0 1 6}$ & $\mathbf{2 0 1 7}$ & Average & $\mathbf{2 0 1 6}$ & $\mathbf{2 0 1 7}$ & Average \\
\hline Aurora-1 & $10.0 \mathrm{bB} *$ & $12.1 \mathrm{cA}$ & 11.1 & $0.76 \mathrm{cA}$ & $0.49 \mathrm{eB}$ & 0.62 & $13.2 \mathrm{cB}$ & $25.5 \mathrm{bA}$ & 19.4 \\
Bonão & $8.1 \mathrm{cB}$ & $9.4 \mathrm{dA}$ & 8.8 & $0.74 \mathrm{cA}$ & $0.66 \mathrm{dA}$ & 0.70 & $11.1 \mathrm{~dB}$ & $14.5 \mathrm{dA}$ & 12.8 \\
BR-1 & $13.7 \mathrm{aB}$ & $17.7 \mathrm{aA}$ & 15.7 & $0.47 \mathrm{dA}$ & $0.61 \mathrm{dA}$ & 0.54 & $29.2 \mathrm{aA}$ & $29.4 \mathrm{aA}$ & 29.3 \\
Charme & $12.9 \mathrm{aA}$ & $11.2 \mathrm{cA}$ & 12.1 & $0.62 \mathrm{cA}$ & $0.49 \mathrm{eA}$ & 0.55 & $20.6 \mathrm{bA}$ & $23.1 \mathrm{bA}$ & 21.9 \\
Chimarrita & $11.8 \mathrm{aA}$ & $13.2 \mathrm{cA}$ & 12.5 & $0.64 \mathrm{cA}$ & $0.50 \mathrm{eA}$ & 0.57 & $18.8 \mathrm{bB}$ & $26.3 \mathrm{bA}$ & 22.5 \\
Coral & $12.3 \mathrm{aA}$ & $12.0 \mathrm{cA}$ & 12.1 & $0.46 \mathrm{dA}$ & $0.50 \mathrm{eA}$ & 0.48 & $26.8 \mathrm{aA}$ & $24.1 \mathrm{bA}$ & 25.4 \\
Douradão & $10.0 \mathrm{bB}$ & $13.3 \mathrm{cA}$ & 11.7 & $0.58 \mathrm{dA}$ & $0.56 \mathrm{eA}$ & 0.57 & $17.8 \mathrm{bB}$ & $24.2 \mathrm{bA}$ & 21.0 \\
Eldorado & $13.0 \mathrm{aB}$ & $18.0 \mathrm{aA}$ & 15.5 & $1.37 \mathrm{bA}$ & $1.02 \mathrm{cB}$ & 1.20 & $9.5 \mathrm{~dB}$ & $17.6 \mathrm{cA}$ & 13.5 \\
Fascínio & $12.7 \mathrm{aA}$ & $13.4 \mathrm{cA}$ & 13.0 & $0.70 \mathrm{cA}$ & $0.55 \mathrm{eB}$ & 0.63 & $18.5 \mathrm{bB}$ & $24.7 \mathrm{bA}$ & 21.6 \\
Kampai & $13.1 \mathrm{aA}$ & $12.5 \mathrm{cA}$ & 12.8 & $0.66 \mathrm{cA}$ & $0.47 \mathrm{eB}$ & 0.57 & $20.0 \mathrm{bB}$ & $27.5 \mathrm{aA}$ & 23.8 \\
Leonense & $13.0 \mathrm{aB}$ & $15.9 \mathrm{bA}$ & 14.5 & $1.70 \mathrm{aA}$ & $1.54 \mathrm{aB}$ & 1.62 & $7.7 \mathrm{eB}$ & $10.5 \mathrm{eA}$ & 9.1 \\
Maciel & $13.8 \mathrm{aA}$ & $15.0 \mathrm{bA}$ & 14.4 & $1.26 \mathrm{bA}$ & $1.28 \mathrm{bA}$ & 1.27 & $11.0 \mathrm{dA}$ & $11.8 \mathrm{eA}$ & 11.4 \\
Marli & $13.3 \mathrm{aA}$ & $12.7 \mathrm{cA}$ & 13.0 & $0.44 \mathrm{dA}$ & $0.41 \mathrm{eA}$ & 0.42 & $30.4 \mathrm{aA}$ & $31.8 \mathrm{aA}$ & 31.1 \\
Ouromel & $11.4 \mathrm{bA}$ & $11.7 \mathrm{cA}$ & 11.5 & $0.58 \mathrm{dA}$ & $0.50 \mathrm{eA}$ & 0.54 & $19.7 \mathrm{bA}$ & $23.6 \mathrm{bA}$ & 21.7 \\
Regalo & $10.9 \mathrm{bB}$ & $12.7 \mathrm{cA}$ & 11.8 & $0.57 \mathrm{dA}$ & $0.71 \mathrm{dA}$ & 0.64 & $19.4 \mathrm{bA}$ & $18.3 \mathrm{cA}$ & 18.9 \\
Rubimel & $10.6 \mathrm{bB}$ & $15.4 \mathrm{bA}$ & 13.0 & $0.63 \mathrm{cA}$ & $0.51 \mathrm{eA}$ & 0.57 & $16.9 \mathrm{bB}$ & $30.7 \mathrm{aA}$ & 23.8 \\
Zilli & $10.5 \mathrm{bB}$ & $13.9 \mathrm{cA}$ & 12.2 & $0.68 \mathrm{cA}$ & $0.63 \mathrm{dA}$ & 0.66 & $15.4 \mathrm{cB}$ & $22.0 \mathrm{bA}$ & 18.7 \\
\hline Average & 11.8 & 13.5 & 12.7 & 0.76 & 0.67 & 0.72 & 18.0 & 22.7 & 20.3 \\
\hline CV (\%) & & 3.4 & & & 14.1 & & & 6.5 & \\
\hline
\end{tabular}

* Means followed by the same lowercase letter in columns and uppercase in rows, do not differ among themselves as determined by the Scott \& Knott test $(\mathrm{p} \leq 0.05)$; CV= Coefficient of variation.

The SS content indicated that most cultivars produced fruits in 2017 that were approximately $15 \%$ sweeter than those produced in 2016 (Table $3)$. The sweetest fuits of all were produced by the cultivars BR-1 (17.7 ${ }^{\circ}$ Brix) and Eldorado (18.0 ${ }^{\circ}$ Brix) in 2017. Bonão, a cultivar commonly harvested for industrial processing, produced the least sweet fruits in both years $\left(8.1^{\circ}\right.$ Brix and 9.4 ${ }^{\circ}$ Brix, respectively).

The TA levels in fruits of Aurora-1, Eldorado, Fascínio, Kampai, and Leonense were lowest in 2017, whereas TA values of the other cultivars were statistically equal between the two crops. The cultivar with the highest fruit TA index in both harvests was Leonense, followed by Maciel and Eldorado in 2016, and by Maciel in 2017 (Table
3). Fruits of the white pulp cultivars: BR-1, Coral, Kampai, and Marli, and the yellow pulp Rubimel had the highest SS/TA ratios in one or both crop cycles.

Regarding the physical fruit quality, an interaction between the two experimental factors (cultivars and crop cycles) was observed only for parameter $a^{*}$ of epidermal background color, and pulp firmness. For the $L^{*}$ and $b^{*}$ parameters of epidermal background color, there was no statistical difference within each factor in isolation (Table 4).

With few exceptions, the parameter $a^{*}$ values of the fruits were higher in 2017 (Table 4), indicating greater biosynthesis and accumulation of red pigments in the epidermis, which made 
the fruits more visually attractive. In 2016, fruits of the cultivar Bonão showed a high index of red epidermal pigmentation in comparison with fruits of the other cultivars, even though Bonão fruits are cultivated for industrial processing. The cultivars that produced fruits with the lowest parameter $a^{*}$ values in 2016 were Fascínio, Leonense, Ouromel, Regalo, Rubimel, and Zilli. In 2017, the cultivars Leonense and Regalo again accumulated less red epidermal pigment (Table 4).

Table 4

Physical fruit quality of peaches produced during the 2016 and 2017 crop cycles. Dois Vizinhos, Paraná States, Brazil

\begin{tabular}{|c|c|c|c|c|c|c|c|c|}
\hline \multirow{2}{*}{$\begin{array}{l}\text { Cultivar/ } \\
\text { Year }\end{array}$} & \multirow{2}{*}{$\begin{array}{c}\begin{array}{c}\text { Epidermis } \\
\text { color }\left(L^{*}\right)\end{array} \\
\text { Average }\end{array}$} & \multicolumn{3}{|c|}{$\begin{array}{l}\text { Epidermis } \\
\text { color }\left(a^{*}\right)\end{array}$} & \multirow{2}{*}{$\begin{array}{c}\begin{array}{c}\text { Epidermis } \\
\text { color }\left(b^{*}\right)\end{array} \\
\text { Average }\end{array}$} & \multicolumn{3}{|c|}{$\begin{array}{c}\text { Pulp firmness } \\
(\mathrm{kg})\end{array}$} \\
\hline & & 2016 & 2017 & Average & & 2016 & 2017 & Average \\
\hline Aurora-1 & $63.8 \mathrm{~ns}$ & $9.3 \mathrm{bB} *$ & $25.7 \mathrm{aA}$ & 17.5 & $31.5 \mathrm{~ns}$ & $6.4 \mathrm{aA}$ & $4.0 \mathrm{bB}$ & 5.2 \\
\hline Bonão & 64.6 & $58.0 \mathrm{aA}$ & $11.8 \mathrm{aB}$ & 34.9 & 67.0 & $3.9 \mathrm{bA}$ & $2.9 \mathrm{bA}$ & 3.4 \\
\hline BR-1 & 54.6 & $5.2 \mathrm{cB}$ & $20.4 \mathrm{aA}$ & 12.8 & 26.2 & $3.3 \mathrm{bA}$ & $2.5 \mathrm{bA}$ & 2.9 \\
\hline Charme & 46.4 & $10.1 \mathrm{bA}$ & $13.9 \mathrm{aA}$ & 12.0 & 23.8 & $6.8 \mathrm{aA}$ & $2.0 \mathrm{bB}$ & 4.4 \\
\hline Chimarrita & 56.4 & $6.0 \mathrm{cB}$ & $14.3 \mathrm{aA}$ & 10.1 & 26.1 & $8.1 \mathrm{aA}$ & $5.5 \mathrm{aB}$ & 6.8 \\
\hline Coral & 52.6 & $3.0 \mathrm{cB}$ & $16.6 \mathrm{aA}$ & 9.8 & 26.2 & $4.9 \mathrm{bA}$ & $2.4 \mathrm{bB}$ & 3.6 \\
\hline Douradão & 44.2 & $2.8 \mathrm{cB}$ & $15.9 \mathrm{aA}$ & 9.3 & 28.9 & $8.3 \mathrm{aA}$ & $3.8 \mathrm{bB}$ & 6.1 \\
\hline Eldorado & 61.5 & $3.0 \mathrm{cB}$ & $12.9 \mathrm{aA}$ & 8.0 & 40.9 & $4.5 \mathrm{bA}$ & $3.4 \mathrm{bA}$ & 3.9 \\
\hline Fascínio & 59.8 & $1.7 \mathrm{~dB}$ & $12.0 \mathrm{aA}$ & 5.1 & 30.1 & $6.7 \mathrm{aA}$ & $6.7 \mathrm{aA}$ & 6.7 \\
\hline Kampai & 47.5 & $7.7 \mathrm{bB}$ & $15.1 \mathrm{aA}$ & 11.4 & 22.8 & $7.1 \mathrm{aA}$ & $4.0 \mathrm{bB}$ & 5.6 \\
\hline Leonense & 58.1 & $1.9 \mathrm{~dB}$ & $5.9 \mathrm{bA}$ & 2.0 & 43.2 & $5.9 \mathrm{aA}$ & $6.2 \mathrm{aA}$ & 6.1 \\
\hline Maciel & 58.3 & $2.7 \mathrm{cB}$ & $14.9 \mathrm{aA}$ & 8.8 & 43.5 & $5.5 \mathrm{aA}$ & $6.2 \mathrm{aA}$ & 5.9 \\
\hline Marli & 54.7 & $5.3 \mathrm{cB}$ & $11.3 \mathrm{aA}$ & 8.3 & 27.1 & $6.2 \mathrm{aA}$ & $5.6 \mathrm{aA}$ & 5.9 \\
\hline Ouromel & 51.8 & $1.0 \mathrm{~dB}$ & $17.6 \mathrm{aA}$ & 9.3 & 34.8 & $6.4 \mathrm{aA}$ & $1.4 \mathrm{bB}$ & 3.9 \\
\hline Regalo & 56.7 & $1.6 \mathrm{~dB}$ & $7.6 \mathrm{bA}$ & 4.6 & 51.2 & $4.8 \mathrm{bB}$ & $6.8 \mathrm{aA}$ & 5.8 \\
\hline Rubimel & 52.6 & $0.6 \mathrm{~dB}$ & $17.1 \mathrm{aA}$ & 8.8 & 34.4 & $5.8 \mathrm{aA}$ & $2.6 \mathrm{bB}$ & 4.2 \\
\hline Zilli & 47.0 & $0.6 \mathrm{~dB}$ & $12.5 \mathrm{aA}$ & 6.5 & 30.3 & $6.3 \mathrm{aA}$ & $5.9 \mathrm{aA}$ & 6.1 \\
\hline Average & 54.8 & 6.7 & 14.4 & 10.6 & 34.6 & 5.9 & 4.2 & 5.1 \\
\hline CV (\%) & 41.7 & & 21.6 & & 28.2 & & 26.2 & \\
\hline
\end{tabular}

* Means followed by the same lowercase letter in columns and uppercase in rows, do not differ among themselves as determined by the Scott \& Knott test $(\mathrm{p} \leq 0.05)$; ns= not significant; $\mathrm{CV}=$ Coefficient of variation.

The pulp firmness of the fruits was higher for the 2016 crop, or statistically equal to that for the 2017 crop, depending on the cultivar (Table 4). An exception was the cultivar Regalo, which showed firmer fruits in 2017. During both crop cycles, the cultivars Chimarrita, Fascínio, Leonense, Maciel, Marli, and Zilli produced fruits with greater pulp firmness, and Bonão, BR-1, Coral, and Eldorado produced lesser firm fruits (Table 4).

\section{Discussion}

Fruit harvest dates

Peach harvest dates depend largely on the cultivars and the weather conditions of the places of cultivation, especially the temperature. For the Kampai cultivar, for example, the fruit harvest in Pelotas (Rio Grande do Sul), usually starts in midNovember; in Atibaia (São Paulo), it starts in the 
second half of October (Raseira, Nakasu, Ueno, \& Scaranari, 2010) and, in Dois Vizinhos (Southwest of Paraná), peaches are harvested from the end of October to the beginning of November, depending on the year (Table 1).

The early harvest of peaches, carried out in mid-October for the cultivars Aurora-1, Bonão, Douradão, Fascínio, Ouromel, Rubimel, and Zilli, can provide a great competitive advantage for the producer by enabling the commercialization of their produce at a time of low supply and best price. In practice it is also observed that the fruit of the earliest peach cultivars suffers less damage from pests and diseases, reducing the need for application of pesticides. These two factors can increase profitability for producer and hence enable the cultivation of peaches in subtropical and/or tropical regions.

\section{Fruit yield components}

The low number of fruits produced by the Kampai cultivar could be attributed to the immaturity of the trees at the time of this study, with the expectation of an increase in number of fruits in subsequent seasons as the trees reached reproductive maturity.

The higher fresh fruit biomasses observed in 2016 for most of the cultivars suggest that, in this year, the greater number of winter hours of cold (HC) below $7.2{ }^{\circ} \mathrm{C}(185 \mathrm{HC}$ in 2016 against 107 $\mathrm{HC}$ in 2017) and the weather conditions in spring were more favorable for peach trees, stimulating greater bud sprouting intensity, greater vegetative growth of branches, increased photosynthetic rate and, consequently, greater availability of photoassimilates for fruit growth. In 2017, the low fresh fruit biomasses of the cultivars Aurora- 1 and Ouromel could be explained by a combination of the less favorable $\mathrm{HC}$ and weather conditions, which would have limited sprouting and fruit quality, and the large number of fruits produced per tree which would have increased competition for photoassimilates between individual fruits.
The quality of fruit, including peaches, is determined by a set of characteristics, such as size (biomass), color, flavor and phytosanitary status. Fruits with good characteristics facilitate marketing, enable the opening of new markets, attract consumers (Dussi, Giardina, Reeb, Bernardin, \& Apendino, 2006), and generally provide greater income for producers. Fruit size is determined by the genetic characteristics of each cultivar, influenced by the general management in the orchard (Giovanaz et al., 2014).

The majority of the cultivars were more productive in 2016, however the cultivar Kampai was an exception as it was more productive in 2017 than in 2016, possibly due to increased age of the trees and associated reproductive maturity. The greater accumulated rainfall in September 2016 compared to the same period in 2017 is likely to have facilitated the observed higher productivity of most cultivars that year.

In the municipality of Lapa, Paraná, the cultivars Chimarrita, Eldorado, Maciel, and Marli were the most productive (Alves, Silva, May de Mio, \& Biasi, 2012). A study by Souza et al. (2017), showed the cultivars Bonão, Ouromel-4, and Maciel to have greater adaptability and stability of the vegetative phase and Ouromel-4 showed the greatest adaptability and stability of the reproductive phase under the subtropical conditions in Lavras, Minas Gerais.

Despite the important effects of climatological factors during flowering and fruit development on the productivity of cultivars, it is possible to infer that, with the exception of Bonão, Charme, and Eldorado, all other cultivars evaluated in this study in Dois Vizinhos, Paraná State require more winter cold than occurred in 2016 (185 HC). It is also important to note that the trees of the cultivars Fascínio, Kampai, Regalo, and Zilli were younger than the others, and they had not reached full reproductive maturity at the time of the study. These cultivars should be evaluated for another two or 
three crop cycles. However, the productivity of the Kampai trees increased by $355 \%$ between the 2016 and 2017 crop cycles, whereas the productivity of the Zilli trees decreased by $296 \%$ (Table 2). This finding suggests that Kampai is a cultivar better adapted to the local climate than Zilli. The Regalo trees seemed to require more winter cold (over $185 \mathrm{HC}$ ) than the Zilli trees, indicating that Zilli is possibly the least adapted of the four cultivars.

Other factors may have contributed to the low yields of some of the peach cultivars evaluated in this study, including the occurrence of frost recorded on 17 and 18 July 2016 and 18 and 19 July 2017 (data not shown). The occurrence and intensity of frost, depending on the phenological stage of the peach trees, can cause abscission of flowers and fruits, especially if it occurs during the initial stage of development (Assmann et al., 2008).

For other cultivars, low productivity can be associated with relatively prolonged periods of water deficit (Mirás-Avalos et al., 2013), such conditions occurred between mid-July and mid-September, 2016 (Figure 1A) and between late August and late September, 2017 (Figure 1B). This environmental factor is likely to have contributed to a lower rate of fruit growth and, consequently, to the low productivity of most of the evaluated cultivars. The water deficit and/or high temperatures, especially in 2017, might have increased the abscission of flowers and particularly of fruits in early development. However, it is possible that some cultivars may have benefited from short periods of water deficit, during both years, especially while flowering and at the start of fruit development. These dry periods may have facilitated adequate pollination and/or reduced the development of diseases of the flowers and fruits.

According to Nava et al. (2009), record high temperatures (daytime and/or nighttime) during preflowering, full bloom and initial fruit development drastically reduced the effective fruiting and productivity of the peach, cultivar Granada, in southern Brazil. These authors suggest that the high temperatures caused a delay in the development of the ovular embryo sac, collapse (abortion), and low rates of pollen grain germination, as well as the abscission of fruits in their initial stage of development.

\section{Physicochemical fruit quality}

According to Morais, Xavier, Silva, Oliveira and Bruckner (2017), the physicochemical fruit quality of peaches intended for fresh consumption varies between crops, and this variation depends on, among other factors, the conditions of the place of cultivation.

The high average SS content observed in the fruits of the majority of the cultivars in 2017 suggested that, due to the failure of sprouting of the vegetative buds as a consequence the scarcity of winter cold, more light entered the tree canopies and reached the developing fruits, resulting in their sweetness. Lower accumulated precipitation and, consequently, greater solar radiation in September 2017 were also possible contributing factors to the high levels of SS and red pigment in the epidermis.

Another factor that may have contributed to this result was the smaller size of the fruits produced in 2017 (Table 2), probably influenced by the limited amount of winter cold and the lower rainfall, leading to an increase in their sugar concentration. On the other hand, the higher levels of tree leafing in 2016, together with failure to perform green pruning most likely restricted the entry of light into the canopy, possibly increasing the acidity in the fruits of the Aurora-1, Eldorado, Fascínio, Kampai, and Leonense cultivars.

It is suggested that the higher values of the SS/TA ratio in fruits of the cultivars BR-1, Coral, Kampai, Marli (white pulp), and Rubimel (yellow pulp) were mainly due to the low acidity of the fruits (Table 3). Based on this quality attribute, these would be the more suitable cultivars for 
fresh consumption, however the same did not have good climate adaptation in the Southwest region of Paraná, with the exception of Kampai, which needs to be studied further until the trees of this cultivar reach reproductive maturation.

The ideal SS/TA ratio range for fresh consumption peach cultivars varies from 13.3-26.7 (Chitarra \& Chitarra, 2005). For most of the cultivars researched in this study, the ratio was within this range with an average of 20.3 (Table 3), indicating that the fruits produced in Dois Vizinhos, Paraná were within the quality standards required by the consumer for this ratio. The dual-purpose cultivars Leonense (9.1), Maciel (11.4), and Bonão (12.8), had the lowest SS/ TA ratios because they had, especially in the first year, higher levels of titratable acidity in their fruits (Table 3).

When grown in Araucária, Paraná, the fruits of the Douradão and Rubimel cultivars showed a better balance between SS and moderate acidity, and matured earlier than those produced by Charme and Chimarrita (Alves et al., 2018). The fruits of the cultivars Coral and Rubimel showed a better balance between SS and TA when grown in Viçosa, Minas Gerais (Matias et al., 2014), demonstrating the effect of different edaphoclimatic conditions on the variability of the chemical attributes related to fruit quality.

The higher values obtained for parameter $a^{*}$ of peach epidermis background color for most of the cultivars in 2017 were in line with what has already been discussed for fresh fruit biomass and SS content, particularly that, in 2017, there was a lower rate of bud sprouting and less vegetative growth of the branches, enabling a higher incidence of solar radiation to reach the fruits, thus increasing their epidermal pigmentation.

Regarding pulp firmness, in addition to genetics (intrinsic differences between the cultivars), a possible explanation for the observed variability, as well as for parameter $a^{*}$ of epidermal background color, could be associated with the differential ripening of fruits between cultivars and growing seasons.

\section{Conclusion}

Under the edaphoclimatic conditions of the study site, it can be concluded that:

The fruits of the cultivars: Aurora-1, Bonão, Douradão, Fascínio, Ouromel, Rubimel, and Zilli matured early, whereas Eldorado and BR-1 matured later.

Bonão, Charme, and Eldorado were the most productive cultivars. Bonão produced a large number of fruits per tree. Eldorado produced the highest caliber of fruits. BR-1 and Eldorado produced the sweetest fruits, and Leonense produced fruits with greater acidity.

The 2016 crop season provided greater productivity, with fruits of greater caliber and firmness of pulp.

\section{References}

Alvares, C. A., Stape, J. L., Sentelhas, P. C., Gonçalves, J. L. M., \& Sparovek, G. (2013). Köppen's climate classification map for Brazil. Meteorologische Zeitschrift, 22(6), 711-728. doi: 10.1127/0941-2948/ 2013/0507

Alves, G., Gelain, J., Vidal, G. S., Nesi, C. N., May de Mio, L. L., \& Biasi, L. A. (2018). Flowering period and fruit quality of peach trees selections and cultivars in the metropolitan region of Curitiba. Revista Brasileira de Futicultura, 40(3), 1-10. doi: 10.1590/0100-29452018991

Alves, G., Silva, J. da, May de Mio, L. L., \& Biasi, L. A. (2012). Comportamento fenológico e produtivo de cultivares de pessegueiro no Município da Lapa, Paraná. Pesquisa Agropecuária Brasileira, 47(11), 1596-1604. doi: 10.1590/S0100204X2012001100006

Assmann, A. P., Citadin, I., Locatelli, M. C., Scariot, S., Danner, M. A., \& Raseira, M. C. B. (2008). Tolerância de frutos de pessegueiro a geadas. Revista Brasileira de Fruticultura, 30(4), 1030-1035. doi: $10.1590 / \mathrm{S} 0100-29452008000400031$ 
Chitarra, I. M. F., \& Chitarra, A. B. (2005). Pós-colheita de frutas e hortaliças: fisiologia e manuseio (2a ed.). Lavras: UFLA.

Citadin, I., Scariotto, S., Sachet, M. R. S., Rosa, F. J., Raseira, M. C. B., \& Wagner, A. Jr. (2014). Adaptability and stability of fruit set and production of peach trees in a subtropical climate. Scientia Agricola, 71(2), 133-138. doi: 10.1590/S010390162014000200007

Cruz, C. D. (2006). Programa Genes: estatística experimental e matrizes. Viçosa, MG: Universidade Federal de Viçosa.

Day, K., Lopez, G., \& Dejong, T. (2008). Using growing degree hours accumulated thirty days after bloom to predict peach and nectarine harvest date. Acta Horticulturae, 803(20), 163-167. doi: 10.17660/ Acta Hortic.2008.803.20

Della Bruna, E., Moreto, A. L., \& Dalbó, M. A. (2012). Uso do coeficiente de repetibilidade na seleção de clones de pessegueiro para o litoral sul de Santa Cantarina. Revista Brasileira de Fruticultura, 34(1), 206-215. doi: 10.1590/S0100-29452012000100028

Dussi, M. C., Giardina, G., Reeb, P., Bernardin, F., \& Apendino, E. (2006). Fruit thinning effects in the apple cv. 'Royal Gala'. Acta Horticulturae, 151(22), 401-408. doi: 10.17660/ActaHortic.2006.727.48

Fachinello, J. C., Coutinho, E. F., Marodin, G. A. B., Botton, M., \& May De Mio, L. L. (2003). Normas técnicas e documentos de acompanhamento da produção integrada de pêssego. (Documentos, 1). Pelotas: Universidade Federal de Pelotas, FAEL.

Giovanaz, M. A., Fachinello, J. C., Goulart, C., Radünz, A. L., Amaral, P., \& Weber, D. (2014). Produção e qualidade de pêssegos, cv. Jubileu, com uso de fitorreguladores. Revista Ceres, 61(4), 552-557. doi: 10. 1590/0034-737X201461040015

Instituto Brasileiro de Geografia e Estatística (2020). Área e quantidade produzida de pêssegos. Recuperado de https://sidra.ibge.gov.br/tabela/6616\#resultado

Instituto Nacional de Meteorologia (2018). Estação 86927. Dois Vizinhos, PR. Recuperado de http:// www. inmet.gov.br/portal/index.php?r=estacoes/ estacoesAutomaticas

Leonel, S., Pierozzi, C. G., \& Tecchio, M. A. (2011). Produção e qualidade dos frutos de pessegueiro e nectarineira em clima subtropical do estado de São Paulo. Revista Brasileira de Fruticultura, 33(1), 118-128. doi: 10.1590/S0100-29452011005000043
Matias, R. G. P., Bruckner, C. H., Silva, D. F. P. da, Carneiro, P. C. S., \& Oliveira, J. A. A. de. (2017). Adaptability and stability of peach and nectarine cultivars in subtropical climate. Revista Ceres, 64(5), 516-522. doi: 10.1590/0034-737X201764050009

Matias, R. G. P., Silva, D. F. P., Ribeiro, M. R., Silva, J. O. C., Oliveira, S. P., \& Bruckner, C. H. (2014). Características de frutos de pessegueiros cultivados na Zona da Mata de Minas Gerais Characteristics of peach fruits grown in the Zona da Mata of Minas Gerais, Brazil. Ciência Rural, 44(6), 971-974. doi: 10. 1590/S0103-84782014000600003

Mirás-Avalos, J. M., Alcobendas, R., Alarcónb, J. J., Valsesia, P., Génardd, M., \& Nicolás, E. (2013). Assessment of the water stress effects on peach fruit quality and size using a fruit tree model, QualiTree. Agricultural Water Management, 128, 1-12. doi: 10.1016/j.agwat.2013.06.008

Morais, K. D. B., Xavier, B. S., Silva, D. F. P., Oliveira, J. A. A., \& Bruckner, C. H. (2017). Avaliação física e química de frutos de cultivares de pessegueiro. Revista Engenharia na Agricultura, 25(2), 157-163. doi: 10.13083/reveng.v25i2.712

Nava, G. A., Dalmago, G. A., Bergamaschi, H., Paniz, R., Santos, R. P., \& Marodin, G. A. B. (2009). Effect of high temperatures in the pre-blooming and blooming periods on ovule formation, pollen grains and yield of 'Granada' peach. Scientia Horticulturae, 122(1), 37-44. doi: 10.1016/j.scienta.2009.03.021

Raseira, M. C. B., Nakasu, B. H., Ueno, B., \& Scaranari, C. (2010). Pessegueiro: cultivar BRS Kampai. Revista Brasileira de Fruticultura, 32(4), 12751278. doi: 10.1590/S0100-29452011005000009

Scariotto, S., Citadin, I., Raseira, M. C. B., Sachet, M. R., \& Penso, G. A. (2013). Adaptability and stability of 34 peach genotypes for leafing under Brazilian subtropical conditions. Scientia Horticulturae, 155(1), 111-117. doi: 10.1016/j.scienta.2013.03.019

Souza, A. P., Ramos, C. M. C., Lima, A. D., Florentino, H. O., \& Escobedo, J. F. (2011). Comparison of methodologies for degree-day estimation using numerical methods. Acta Scientiarum Agronomy, 33(3), 391-400. doi: 10.4025/actasciagron. v33i3.6018

Souza, F. B. M., Pio, R., Barbosa, J. P. R. A. D., Reighard, G. L., Tadeu, M. H., \& Curi, P. N. (2017). Adaptability and stability of reproductive and vegetative phases of peach trees in subtropical climate. Acta Scientiarum Agronomy, 39(4), 427435. doi: 10.4025 /actasciagron.v39i4.32914 